\title{
Water management from the environmental certification perspective: a new proposal of criteria and weight rates for application in Brazilian regions
}

Gestão da água na perspectiva das certificações ambientais: uma nova proposta de critérios e ponderações para aplicação em regiões do Brasil

Celso Silva Bastos** ${ }^{10}$, João Luiz Calmon' ${ }^{\circledR}$, Ricardo Franci Gonçalves' ${ }^{\circledR}$

\begin{abstract}
Several countries have developed tools with criteria and evaluations to grant, through the environmental certification, a more sustainable undertaking, with quality and productivity for its users. The tools were developed for different needs and objectives, which makes it difficult to make a direct comparison, in addition to having specific demands for each region. This study aims to make a comparative analysis between some tools of greater international knowledge and to propose new parameters for the water use and management category, taking into account the design and operational phase, the water distribution, and the demands for 2025. Consequently, this study proposed the creation of an exclusive environmental tool for the management and water use, providing a seal that may be applied to any project and adopted by water work systems as an incentive to reduce the consumption of drinking water, to use alternative sources, and to decrease liquid effluents.
\end{abstract}

Keywords: environmental assessment tools; water efficiency; sustainability; green buildings; water reuse; alternative water source.

\section{RESUMO}

Vários países desenvolveram ferramentas com critérios e avaliações para garantir um empreendimento mais sustentável, com qualidade e produtividade para seus usuários, por meio de certificação ambiental. As ferramentas foram desenvolvidas para diferentes necessidades $e$ objetivos, o que dificulta a comparação direta, além de haver demandas específicas para cada região. Este estudo teve como objetivo fazer uma análise comparativa entre algumas ferramentas de maior conhecimento internacional e propor novos parâmetros para a categoria de uso e gestão da água, levando em conta a fase de projeto e operação, a distribuição de água e as demandas para 2025. Consequentemente, este estudo propôs a criação de uma ferramenta ambiental exclusiva para a gestão e o uso da água, proporcionando um selo que pode ser aplicado a qualquer projeto e adotado pelas concessionárias de água como incentivo para reduzir o consumo de água potável, usar fontes alternativas e diminuir os efluentes líquidos.

Palavras-chave: ferramentas de avaliação ambiental; eficiência hídrica; sustentabilidade; construções verdes; reúso de água; fontes alternativas de água.

\section{INTRODUCTION}

The world has been facing a serious and growing water problem, which can particularly compromise supply in countries with water crisis and constant shortage mainly due to urban growth, increasing the water demand. According to Taylor and Sonnenfeld (2017), water crises tend to deepen severely and unpredictably, being affected by the uncontrolled growth of population, water demand, droughts, and events associated with global climate change.

In order to reduce and mitigate the impacts caused by construction to the environment, several environmental assessment tools have emerged to certify green buildings. Andrade and Bragança (2016) reported that the sustainability concept is not consensual because it is subjective and the differences between tools can make it difficult to be used or to compromise users' confidence. In addition, the author highlights that even the adopted terminology is different from tool to tool.

Water is extracted from natural sources daily and processed in large amounts to obtain high quality drinking water. The corresponding wastewater should be treated before being released into the wild, minimizing interference with the springs. A sustainable building can, 
and should, be economically feasible, considering that the certificates also have a market role and comply with legal requirements, which go beyond environmental causes. The reasons that lead an entrepreneur to opt for a certain tool are defined by several factors that can vary per region, legal constraints, and intended results.

According to Darko and Chan (2016) and Yuan and Shen (2011), there is a great interest by researchers in identifying the regional contributions to better performance of green buildings. Due to the need of addressing issues in local settings of specific countries or regions, different classification systems have a different emphasis, says Doan et al. (2017).

Suzer (2015) emphasizes that some nationally developed certification systems are used without regional adaptations, which may lead to results that do not correspond to the purposes of local sustainability or construction. Also, further adjustments in the system structure for regional variations between countries should be introduced in order to facilitate their international application. Pahl-Wostl (2015) points out that the greatest relations between humans and the natural world are directly affected when there are water crises, as they are also sustainability crises.

Sallam and Abdelaal (2015) corroborate that tools need adaptation, modification, and perhaps aggregation with other tools to reflect a reliable performance. The importance and priorities are different between the regions and the local environment; therefore, the assigned credits need to be adjusted. Thus, a baseline for analysis of issues related to water efficiency is proposed in the area of the United Arab Emirates. Such author also states that input, output and process methodologies should be reviewed, and new priorities should be considered individually in each region and country before they are implemented and approved.

Assessment tools are continuously in the improvement process regarding reliable data on water consumption and water supply. It is impossible to previously measure the practices of use in constructions at operation, since even an enterprise that has been contemplated with concepts to reduce drinking water consumption and use alternative sources or even with a good action plan to contain losses and wastes, it is the cautious use that may guarantee a good result in terms of reduction of consumption and of liquid effluents.

The performance of constructions contributes to sustainable development and environmental impacts, as stated by Ding (2008), who stresses that there are two environmental types of evaluation: one based on criteria and another that uses life cycle assessment as methodology, according to Ali and Al Nsairat (2009).

The use of the a methodology that evaluates life cycle makes the process more complex and with future data based on assumptions related to the long life of a building. Bribián, Usón and Scarpellini (2009) commented that the certifications should make use of the life cycle evaluation, but it becomes unfeasible due to its complexity. It does not always have access to the necessary inventories and information to meet the needs of a life cycle analysis.

Sallam and Abdelaal (2015) report that the World Green Building Council (WGBC) states that each country has different climatic and environmental conditions and that a single tool may not be suitable for global use, as regional differences may affect categories, such as water resources and availability. According to Sev (2011), regional and cultural differences, as well as priorities, must be considered, making the system feasible and applicable with real conditions and accuracy. Defining regional system boundaries is also important for customizing and determining the priority of each performance criterion.

The methodology of this study consists of a comparative analysis of environmental certification tools, reviewing published literature and citations for a scenario with a holistic view of how the water use and management issue is considered and measured in the tools. The research was based on the available tool methods, which is internationally acknowledged and currently in use.

Considering the gap in research directed to local realities, this study aimed to make a comparative analysis of some existing tools and to propose new parameters for the water use and management category, taking into account the design and operational phase. Therefore, a new tool was proposed considering the regional differences of Brazil that could be used by the water work systems and as a complement to the water criterion of other tools in Brazil.

\section{CERTIFICATIONS, PURPOSES, AND INTERESTS}

According to the guide of Core Net Global (2014), there are some factors that guide the entrepreneur to define whether or not to certify and what would be the best system for the future enterprise, such as legal requirements, investor or renter profile, economic factors, market dynamics, and incentives for both taxes and urban rates.

In some countries, such as Australia, Canada and the USA, there is an obligation to comply with environmental requirements that, depending on the case, will be the initial factor for directing a system that complies with the law. In Brazil, environmental certifications for construction are voluntary, even for public buildings, which does not exempt, in many cases, from the obligation of developing an environmental control plan and a neighborhood impact study, which has no association with certifications, but that meets some criteria of existing systems, except for the National Program of Conservation of Electric Energy (Procel) - in the field of energy, mandatory in public buildings. 
The market also dictates decisions. An investor, owner or tenant may opt for an enterprise that fulfills the expected performance of a sustainable construction, which in some cases may be linked to the need for its activities, as well as to provide a more productive and quality environment for its users. There is the choice preference, for a certified work, which means faster sales and valuation of the property.

In short, the minimum legal and market requirements can define the level of certification. The market may have an above-legal expectation, leading the entrepreneur to define it by a goal above the one originally planned, protecting the entrepreneur against the risk of future obsolescence as a result of increasing demands for sustainability.

Cole (2005) comments that it is not possible to not recognize that the application of systems categorizing undertakings through their performance brings positive gains in the social, economic and environmental area, leading to a growing practice in developing countries. The decision for a certification involves the entire production chain, which means that manufacturers, suppliers, buyers, designers, and builders are engaged in a holistic way in every process of compliance with the system requirements.

Piccoli et al. (2010) declare that the design phase is the main driver of the whole process. The detailed specifications, containing materials of proven ecological provenance and technical memorials, must comply with the method requests, which may be a completely different procedure from the one used by the company in its routine work.

In addition to the organization practices of the construction site, to the purchase of materials and the inspection and documentation rigor, suppliers also need to adapt to the system requirements and emphasize the importance of a systemic approach to the process of enterprise management, with probable need of requalifying all involved actors, from the workers to the supply chain of materials and components. In conclusion, Piccoli et al. (2010) mention that a new way of looking at civil construction will lead to the search for a certification.

In addition, Grünberg, Medeiros and Tavares (2014) recalls, quoting Medeiros, Andrade and Helene (2011), the extended durability of a building, as said, will bring lower maintenance costs over the years due to its longer service life. Therefore, it will spare the natural resources for the repair, demolition, and reconstruction process. There is no denying the need of reducing the environmental impact caused by the construction industry. This is a new applied and constantly updated concept, in which everyone should be engaged, regardless of market issues or in compliance with current legal requirements. Environmental assessment tools play the role of efficiently guiding how these concepts can be applied, and how an enterprise can gain in terms of durability, performance, and value.
Several studies and surveys carried out by green building segments confirm that companies adopting "good practices" reduce risks to investors, reduce the vacancy rate, value real estate rent, and decrease the condominium fee in certified buildings due to greater efficiency and durability. Sallam and Abdelaal (2015) understand that using an environmental assessment tool is not an obvious thing and that the place, the time, by whom and how to apply the evaluation results, should be very clear so that the results may bring the expected benefits in environmental commitment and basic sustainability pillars.

Environmental assessment systems promote gains as to reductions in the impacts caused by construction and, consequently, increase the performance and service life of an undertaking. In addition, Grünberg, Medeiros and Tavares (2014) apud Bastos and Rebello (2016), considers that the green certificates achieved by the certification methods, whether driven by demand or committed to environment or market issues due to competitiveness, should be adapted to the scenarios of each region where they are intended to be applied.

\section{TOOLS, CRITERIA, AND WEIGHT RATES}

Every certification tool aims to improve the environmental performance of buildings and reduce the impacts caused during construction and after occupation. Through the tools, designers can consider various aspects of sustainable design that are not addressed by building codes, including the manufacturing of materials and products. For a comparison between the methods related to water use, we have selected some of the most used tools in the majority of the countries committed to the performance of projects, as well as their economic, environmental and social impacts, as shown in Table 1.

Each tool assesses the water use from a perspective defined for the country of origin, but it is also possible to be adjusted to other regions such as leadership in energy and environmental design (LEED), which added a credit to regional priorities, and the DGNB that offers the possibility of creating a specific method for use in the intended region. Brazil, which already had the AQUA evaluation system, now has the new version of 2016, the AQUA - HQE, which gains international recognition and the possibility of regional adjustments as per local reality and culture. Figure 1 shows the percentages for each criterion defined in each certification system.

All building classification systems have evolved over the years and have been updated to become more demanding, in line with technological advances. These have led to the evolution of building classification systems, making them more demanding and more notorious and attracting the attention of several countries, including developing countries like Brazil (DOAN et al., 2017). 
Table 1 - Tools, category, weight rates, and certification.

\begin{tabular}{|c|c|c|c|c|c|c|c|}
\hline System & Origin & Year & Definition & Description & $\begin{array}{l}\text { Water } \\
\text { assessment } \\
\text { category }\end{array}$ & \begin{tabular}{c|}
$100 \%$ \\
Consideration
\end{tabular} & Certification \\
\hline $\begin{array}{l}\text { AQUA-HQE www. } \\
\text { vanzolini.org.br }\end{array}$ & Brazil & 2014 & $\begin{array}{l}\text { High } \\
\text { Environmental } \\
\text { Quality }\end{array}$ & $\begin{array}{l}\text { It is an international certification of sustainable } \\
\text { construction developed from the French } \\
\text { certification Démarche HQE (Haute Qualité } \\
\text { Environnementale) and applied in Brazil exclusively } \\
\text { by the Vanzolini Foundation. The evaluation of the } \\
\text { Environmental Quality of the Building is made for } \\
\text { each of the } 14 \text { categories of environmental concern. } \\
\text { For an undertaking to be AQUA-HQE certified, the } \\
\text { entrepreneur must achieve at least a performance } \\
\text { profile with three categories at the BEST PRACTICE } \\
\text { level, four categories at the GOOD PRACTICE level, } \\
\text { and seven categories at the BASE level. }\end{array}$ & $\begin{array}{l}\text { Water } \\
\text { management }\end{array}$ & 12.22 & $\begin{array}{l}\text { Baseline, good } \\
\text { practices and } \\
\text { best practices }\end{array}$ \\
\hline $\begin{array}{l}\text { DE(M) } \\
\text { 建築環保評估協會 } \\
\text { BEAM PLUS www. } \\
\text { hkgbc.org.hk }\end{array}$ & $\begin{array}{l}\text { Hong } \\
\text { kong }\end{array}$ & 2012 & $\begin{array}{l}\text { Building } \\
\text { Environmental } \\
\text { Assessment } \\
\text { Method }\end{array}$ & $\begin{array}{l}\text { HK-BEAM was one of the first schemes to be } \\
\text { developed and launched in } 1996 \text { to guide the } \\
\text { design and evaluation of the overall performance } \\
\text { of new and existing buildings in Hong Kong. Since } \\
\text { then, it has undergone several upgrades to reflect } \\
\text { continued industry improvement, with the latest } \\
\text { version, BEAM Plus (v1.2) released in July } 2012 \text { by the } \\
\text { Hong Kong Green Construction Council (HKGBC). }\end{array}$ & Water use & 6.99 & $\begin{array}{l}\text { one star = } \\
\text { 10-19; two star } \\
\text { = 20-29; three } \\
\text { star = 30-44; } \\
\text { four star = } \\
\text { 45-59; five star } \\
\text { = 60-74; six } \\
\text { star = 75+ }\end{array}$ \\
\hline $\begin{array}{l}\text { BREEAM tools. } \\
\text { breeam.com }\end{array}$ & UK & 1990 & $\begin{array}{l}\text { Building } \\
\text { Research } \\
\text { Establishment } \\
\text { Environmental } \\
\text { Assessment } \\
\text { Method }\end{array}$ & $\begin{array}{l}\text { BREEAM sets the standard for the best practices } \\
\text { in sustainable building design and construction. } \\
\text { Its main objectives are: } 1 \text { - to mitigate the impacts } \\
\text { of the life cycle of buildings on the environment; } \\
2 \text { - to allow buildings to be recognized according } \\
\text { to their environmental benefits; } 3 \text { - to provide a } \\
\text { credible environmental label for buildings; } 4 \text { - to } \\
\text { stimulate demand for sustainable buildings. }\end{array}$ & Water & 5.45 & $\begin{array}{l}\quad<30 \\
\text { unclassified; } \\
>/ 30 \text { pass; }>/ 45 \\
\quad \text { good; }>/ 55 \\
\text { very good; } \\
>/ 70 \text { excellent; } \\
\text { >/outstanding }\end{array}$ \\
\hline $\begin{array}{l}\text { CASBEE 1-NC } \\
\text { www.ibec.or.jp }\end{array}$ & Japan & 2010 & $\begin{array}{l}\text { Comprehensive } \\
\text { Assessment } \\
\text { System for Built } \\
\text { Environmental } \\
\text { Efficiency }\end{array}$ & $\begin{array}{l}\text { It is a method to evaluate and classify the } \\
\text { environmental performance of buildings and } \\
\text { the built environment. It is a comprehensive } \\
\text { assessment of the quality of a building, assessing } \\
\text { features such as interior comfort and scenic } \\
\text { aesthetics, considering environmental practices } \\
\text { that include the use of energy-saving materials or } \\
\text { equipment that achieve lower environmental loads. }\end{array}$ & $\begin{array}{l}\text { LR2-resources } \\
\text { and materials } \\
\text { - water } \\
\text { resources }\end{array}$ & 2.63 & $\begin{array}{l}\text { Superior (S); } \\
\text { very good } \\
\text { (A); good (B+), } \\
\text { slightly poor } \\
\text { (B-); poor (C) }\end{array}$ \\
\hline $\begin{array}{l}\text { DGNB } \\
\text { www.dgnb- } \\
\text { system.de/en }\end{array}$ & Germany & 2014 & $\begin{array}{c}\text { Deutsche } \\
\text { Geesellscharft } \\
\text { für Nachhaltiges } \\
\text { Bauen }\end{array}$ & $\begin{array}{l}\text { The DGNB System covers all fundamental } \\
\text { aspects of sustainable construction: } \\
\text { environmental, economic, sociocultural and } \\
\text { functional aspects, technology, processes and } \\
\text { sites. }\end{array}$ & $\begin{array}{l}\text { Drinking water } \\
\text { demand and } \\
\text { waste water } \\
\text { volume }\end{array}$ & 2.25 & $\begin{array}{l}<35 \% \text { bronze; } \\
35 \% \text { to } 50 \% \\
\text { silver; } 50 \% \\
\text { to } 65 \% \text { gold; } \\
65 \% \text { to } 80 \% \\
\text { platinum }\end{array}$ \\
\hline $\begin{array}{l}\text { GPRS } \\
\text { egypt-gbc.org/ } \\
\text { ratings.html }\end{array}$ & Egypt & 2011 & $\begin{array}{l}\text { Green Pyramid } \\
\text { Rating System }\end{array}$ & $\begin{array}{c}\text { The classification system has three levels for } \\
\text { certification of ecological buildings according to } \\
\text { the Egyptian GPRS. }\end{array}$ & $\begin{array}{l}\text { Water } \\
\text { efficiency }\end{array}$ & 27.27 & $\begin{array}{l}\text { Green, Silver, } \\
\text { and Golden } \\
\text { Pyramid }\end{array}$ \\
\hline $\begin{array}{l}\text { BCA GREEN MARK } \\
\text { GREEN MARK } \\
\text { WWW.bCa.gOV.Sg }\end{array}$ & Singapore & 2005 & \begin{tabular}{|l} 
BCA Green Mark \\
(Singapore's \\
Building \\
Construction \\
Authority-BCA)
\end{tabular} & $\begin{array}{c}\text { Voluntary certification in Singapore with the } \\
\text { aim of promoting "sustainability in the built } \\
\text { environment and increasing environmental } \\
\text { awareness among developers, designers and } \\
\text { builders." }\end{array}$ & $\begin{array}{l}\text { Water } \\
\text { efficiency }\end{array}$ & 8.97 & $\begin{array}{l}50 \text { to } 74 \text { points } \\
\text { = Certified; } 75 \\
\text { to } 84 \text { = Gold; } \\
85 \text { to } 90= \\
\text { Gold Plus and } \\
\text { equal or above } \\
90=\text { silver }\end{array}$ \\
\hline
\end{tabular}


Table 1 - Continuation.

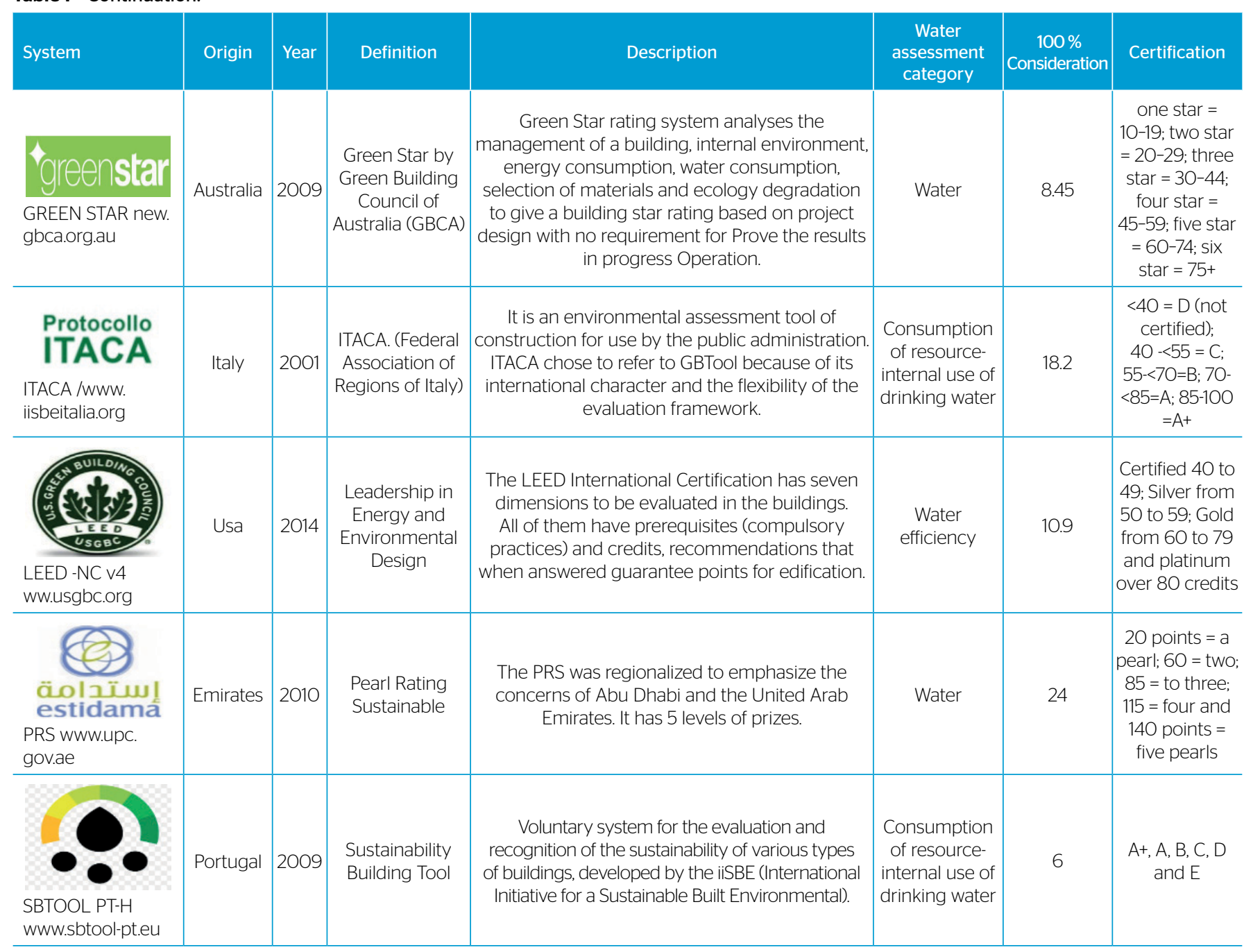

For Nguyen and Altan (2011), the most rigorous tools in environmental issues are BREEAM and LEED, but they all provide designers and entrepreneurs with a systematic and valuable reference source for various research studies related to sustainable development. Lee (2013) has a similar opinion and adds that the data obtained through the criteria of the tools favor adaptations based on the characteristics of each region.

As shown in Figure 1, the disparity between the criteria and the necessary weights in relation to the criterion of water use and management is noted, even in countries with history of water scarcity in part of their territory. Tools such as PRS and GPRS have been developed considering the demands for water in each territory, due to the serious problem that happens today in the United Arab Emirates and in Egypt. Applying a tool without adequate adaptation to the country realities will certainly not lead to satisfactory results.

Table 2 summarizes the criteria for water use and management and the applied weighting. The percentage does not reach $30 \%$ for the criterion of water use, and the GPRS tool has the highest index, $27.27 \%$.
As shown in Figure 1 and Table 2, the GPRS tool, developed to be applied in Egypt, has the highest weighting among all of them, since it was designed for use in a hot and dry region where problems with water scarcity are common and may increase with the possibility of global warming. Asdrubali et al. (2015), comparing the ITACA method with LEED in two residences, identified similar results. They granted $\mathrm{B}$ and green seals, respectively, and the Italian seal presented the highest score in the water use category. There is a clear concern about energy issues regarding water consumption, even in places with history of shortages.

\section{REGIONAL DIFFERENCES IN BRAZIL}

Brazil is considered a country of continental dimensions, with territorial extension of $8,516,000 \mathrm{~km}^{2}$. The large-scale regional and climate variations in the various regions of this country can be understood in terms of the general circulation of the atmosphere, given by the behavior of Hadley-Walker convective cells and frontal systems. These cells 
cause variations in precipitation distribution and are associated with latent heat release during precipitation, with Hadley north-south and Walker east-west.

The interannual variations of precipitation in Brazil are also related to the El Niño and La Niña phenomena.

The Amazon basin - which covers Amazonas, Amapá, Acre, Rondônia, Roraima and a large portion of Pará and Mato Grosso - is equivalent to $45 \%$ of the national territory and holds $81 \%$ of water availability. The coastal regions, which account for only $3 \%$ of the national supply, are a home to $45 \%$ of the country population, that is, Brazilians are increasingly concentrated in areas where water supply is unfavorable. Figure 2 shows the Brazilian mapping and its regional divisions.

Figure 3 provides a graph with the serious history of January 2016, comparing with the average of the year per capital city. In the northeast region, rainfall rates are the lowest in the country, and the severe droughts scourge the entire region and the northeastern population.
Most of the northeastern population inhabits the coastal areas, where the water supply is greater than inland, but still below other country regions.

Table 2 - Summary of weighting per tool.

\begin{tabular}{l|c} 
Tool & \% Água \\
\hline AQUA-HQE & $12.22 \%$ \\
\hline BEAM PLUS & $6.99 \%$ \\
\hline BREEAM & $5.45 \%$ \\
\hline CASBEE & $2.63 \%$ \\
\hline DGNB & $2.25 \%$ \\
\hline GPRS & $27.27 \%$ \\
\hline GREEN MARK & $8.95 \%$ \\
\hline GREEN STAR & $8.95 \%$ \\
\hline ITACA & $18.20 \%$ \\
\hline LEED V4 & $10.09 \%$ \\
\hline PRS & $24.00 \%$ \\
\hline SBTOOL PT & $6.00 \%$ \\
\hline
\end{tabular}

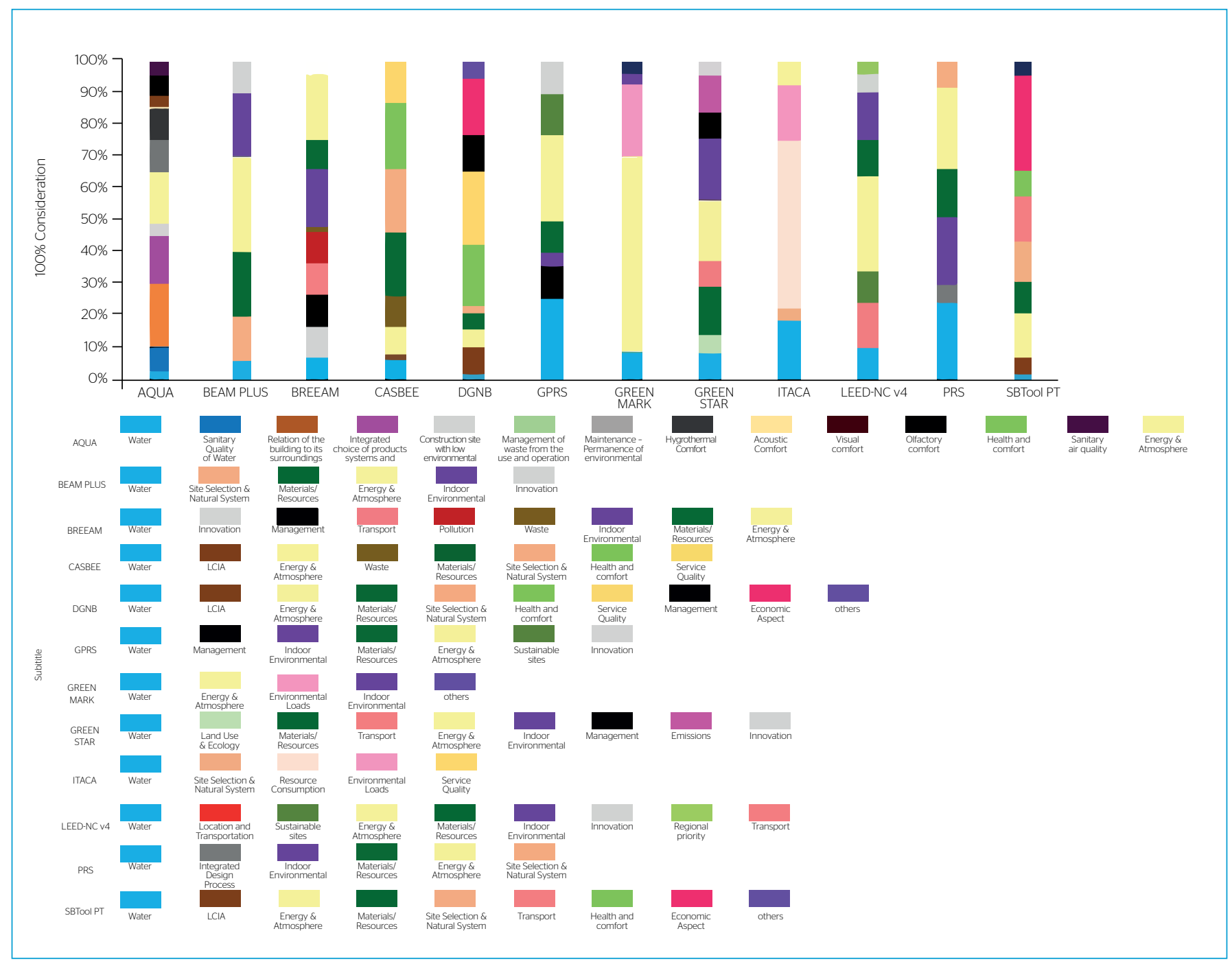

Figure 1 - Criteria and consideration. 
We can see a regional discrepancy between the expected demand and water distribution in Table 3. The sanitation deficit in Brazil can also be observed. Considering that one of the objectives of the tools is to reduce the environmental impacts caused by the civil construction, it is essential to consider the situation regarding the demands and offers for water and to work to preserve the sources, seeking alternative solutions to meet the current and future demands.
Hence, this study proposes parameters for the development of more sustainable projects and includes indispensable procedures in the operation and maintenance phase, always seeking to reach the basic concepts of sustainability, which include the economic, environmental, and social side.

As shown in Table 3, if we compare the predicted demand with the water distribution, the greatest concern for lack of water is not

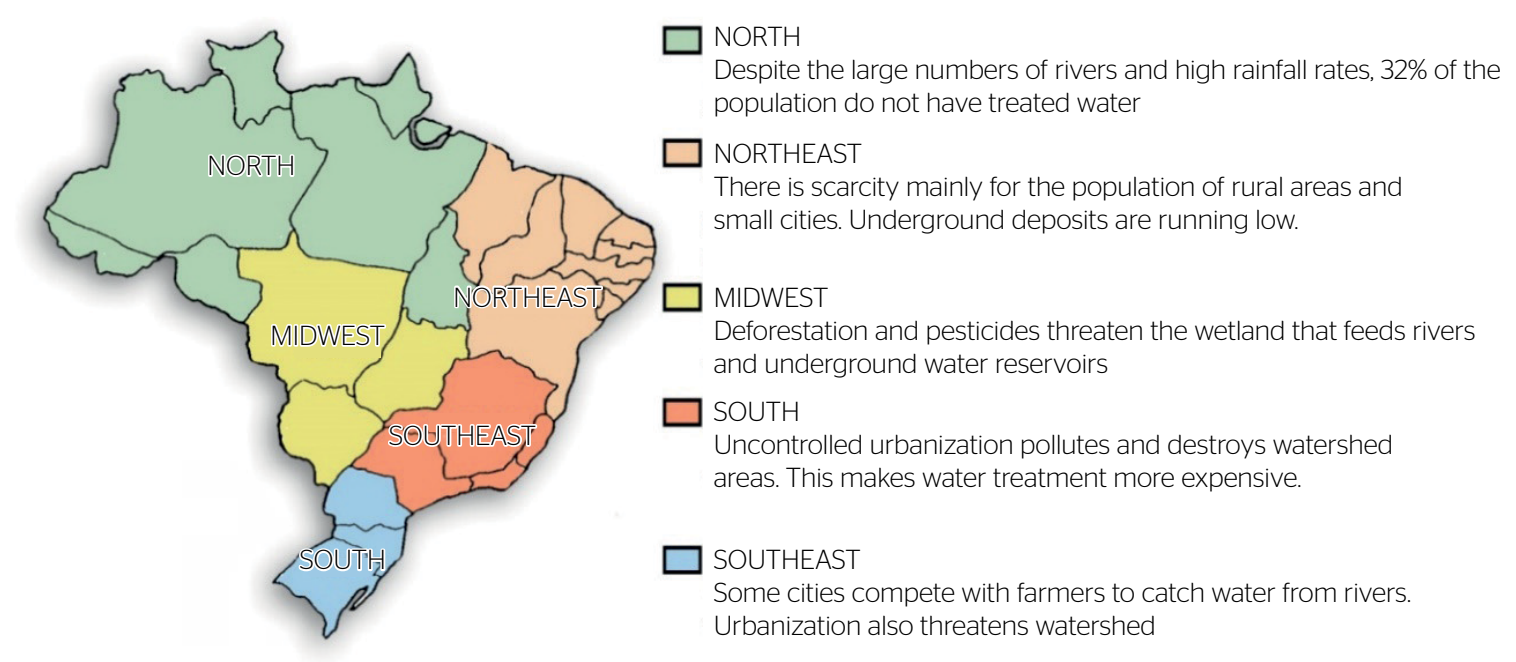

Figure 2 - Regions of Brazil.

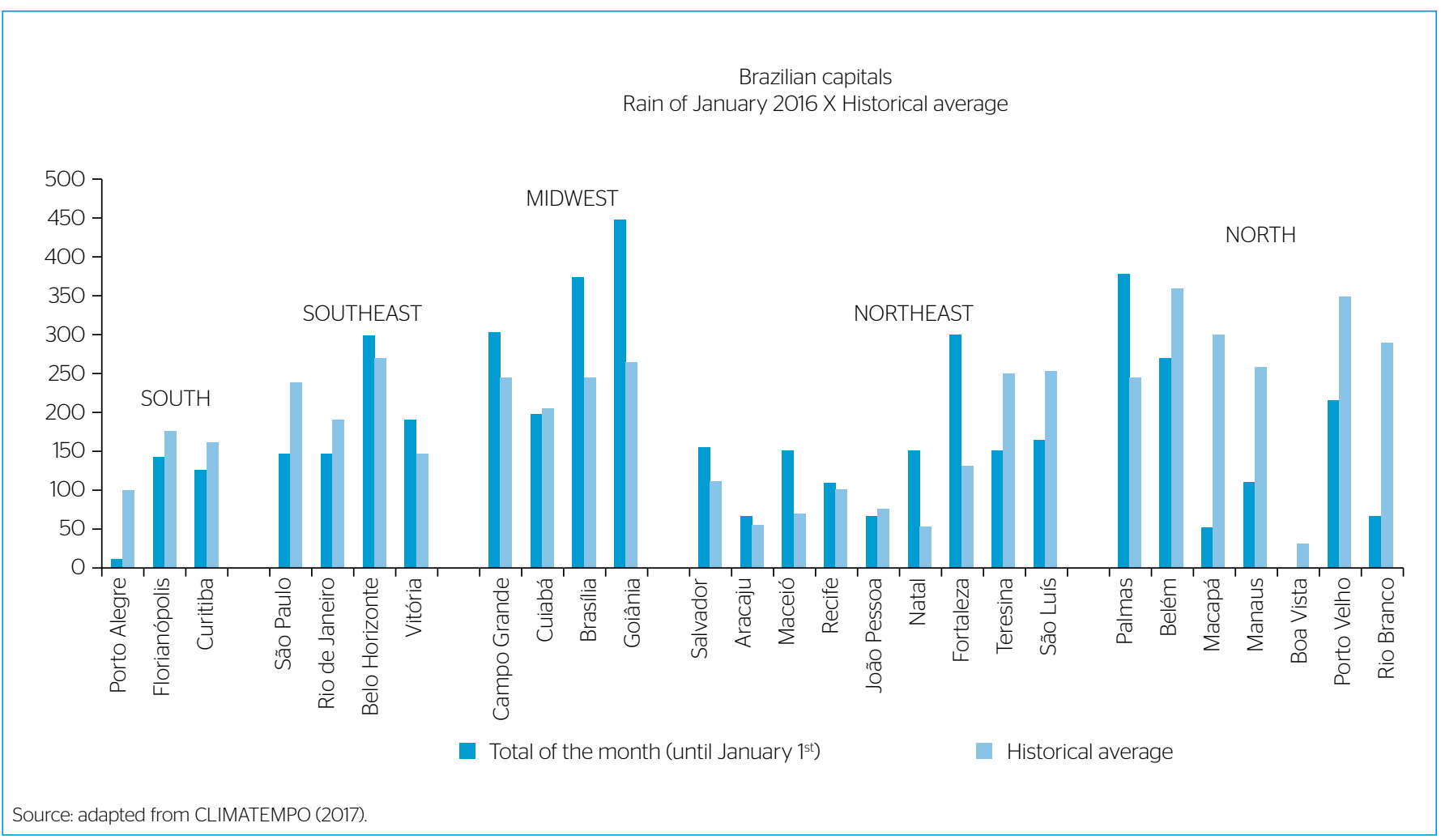

Figure 3 - Precipitation of January 2016 by regions of Brazil × historical average. 
always in regions with less availability. If we compare what will be necessary to what is available, the North region will need around $0.8 \%$ of its availability; the Northeast region, 57 times its availability; the Central West region, 3 times its availability; the Southeast region 54 times its availability; and lastly the South, 13 times the water availability.

Figures 4 present the indices with the demands for 2025 and the water distribution per regions of Brazil.

The highest demand for water comes from the great centers of the Southeast region, where water is increasingly withdrawn from more distant places. The environmental assessment tools applied to the buildings need to be stricter in order to be more efficient in the use and reuse of water. Many tools turn to energy issues and only encourage control over water consumption, but not exactly in what activity this control should be applied.

\section{PROPOSAL FOR A NEW WATER MANAGEMENT TOOL}

Considering that an environmental certification should confer a green seal after verifying and proving the results proposed in the project, this study recommends new criteria and specific weighting for the design and operational phases, as presented in Tables 4 and 5 , in order to guarantee greater efficiency for water conservation and management, which

Table 3 - National demand and distribution scenario.

\begin{tabular}{l|c|c|c|c}
\multicolumn{2}{l|}{ National demand and distribution scenario } & \multicolumn{2}{c}{ Sanitation deficit } \\
\hline Region & $\begin{array}{c}\text { Demand for } \\
2025 \mathrm{l} / \mathrm{s}\end{array}$ & $\begin{array}{c}\text { Water } \\
\text { distribution } \\
(\%)\end{array}$ & $\begin{array}{c}\text { Potable } \\
\text { water (\%) }\end{array}$ & Sewer (\%) \\
\hline North & 54,727 & $68 \%$ & 32.53 & 98.28 \\
\hline Northeast & 170,273 & $3 \%$ & 21.74 & 86.78 \\
\hline Midwest & 48,918 & $16 \%$ & 20.29 & 66.73 \\
\hline Southeast & 322,546 & $6 \%$ & 6.47 & 29.55 \\
\hline South & 91,189 & $7 \%$ & 9.38 & 82.15 \\
\hline Source $A N A(2017)$ & & & & \\
\hline
\end{tabular}

Source: ANA (2017).

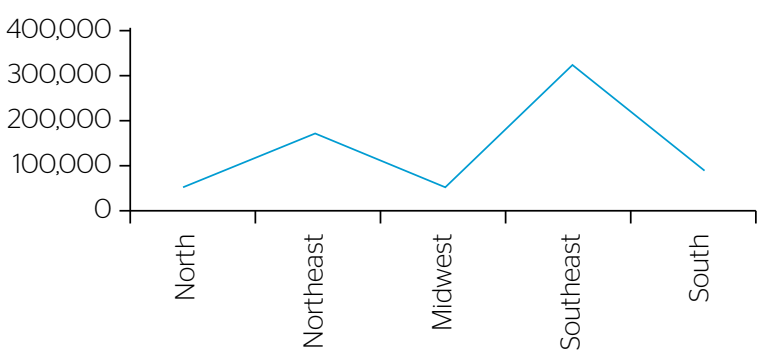

Table 4 - Project Criteria.

\begin{tabular}{c|c|c}
\hline \multicolumn{2}{|c}{ Project criteria - hydrosanitary } & Points \\
\hline 1 & Parameters & $\cdots$ \\
\hline & - Sectorized measuring & 5 \\
\hline 2 & 1.1 - systems & 5 \\
\hline 3 & 1.2 - subsystems & 5 \\
\hline & - Water-saving equipment & $\cdots$ \\
\hline & - Reuse of alternative sources & 5 \\
\hline & 3.1 - greywater & 3 \\
\hline & 3.2 - blackwater & 5 \\
\hline & 3.3 - rainwater & 5 \\
\hline 4 & 3.4 - condensation water & 2 \\
\hline 5 & 3.5 - purge water & 4 \\
\hline 6 & - Leakage detection system & 5 \\
\hline 7 & - Increase in permeable area & 5 \\
\hline 8 & - Greywater and dark greywater (fat) separation & 5 \\
\hline Total & & 60 \\
\hline
\end{tabular}

Table 5 - Operating Criteria.

\begin{tabular}{|c|c|c|}
\hline \multicolumn{3}{|c|}{ Operating criteria } \\
\hline & Parameters & Points \\
\hline 1 & Water use awareness campaign & 3 \\
\hline 2 & Water leakage action brigade & 4 \\
\hline 3 & Regular adjustment of toilet flush and valves & 5 \\
\hline 4 & Irrigation and general washing with reused water & 5 \\
\hline 5 & Replenishing water tower with reused/industrial water & 5 \\
\hline 6 & Goals for reducing monthly consumption of drinking water & 5 \\
\hline 7 & Continuous training of the professionals involved & 4 \\
\hline 8 & Reduction of liquid effluents & 3 \\
\hline 9 & Guaranteeing drinking water quality after intake & 3 \\
\hline 10 & Other & 3 \\
\hline \multicolumn{2}{|c|}{ Total } & 40 \\
\hline
\end{tabular}

WATER DISTRIBUTION (\%)

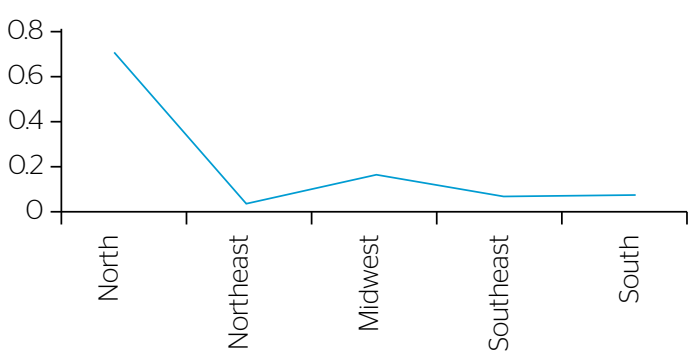

Figure 4 - National demand and distribution scenario. 
can be included in any tools presented in the item corresponding to water efficiency mainly when used in countries with water problems, such as several regions of Brazil.

Thus, the use of alternative water sources, especially for demands that do not depend on drinkability, has become part of water conservation practices, since they reduce pressure on natural resources (NICOLETTE; BURR; ROCKEL, 2013; SINGH; KHEDUN; MISHRA, 2014; WIENER; JAFVERT; NIES, 2016; MUN; HAN, 2012; MOREIRA NETO et al., 2012).

As shown in Figure 1, most tools include a low weighting for the water criterion, even in countries with history of shortages and supply crises such as the USA and Australia. The design definitions, when conceived with concepts of low environmental impact, tend to guarantee a greater efficiency result compared to adapted projects after their execution.

Operational criteria are essential for efficient water management. An undertaking by itself will not guarantee savings only with the projects, even if they have been considered sustainable concepts to reduce the impact of construction on the environment. A holistic view with compatibility between project and operational actions is what is expected for real gain.

\section{PROPOSAL FOR A NEW WATER MANAGEMENT TOOL}

Based on the data published by the Brazilian National Water Agency (ANA, acronym in Portuguese), regarding the prediction of demands for 2025 in all regions of Brazil and with water availability for the same regions, this study proposes the creation of a new tool with parameters and weighting for water use and management to be applied in project designs and to be adopted during the stage of operation and maintenance of the projects in the cities of Brazil.

The new certification is called "+água" (+water) in this proposal, and a visual identity as illustrated in Figure 5 has been created. With focus on the national reality, the tool can be adopted by water and sewage concessionaires in all cities of Brazil to encourage the application of environmental concepts in constructions. Meeting the proposed parameters may bring, in addition to economic gains with

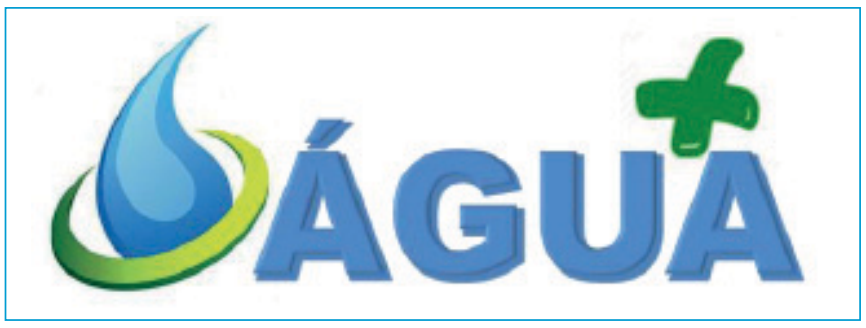

Figure 5 - Tool Logo “+ água”. the consumption reduction of drinking water, social and environmental benefits.

As seen earlier, some tools award green seals with, silver, bronze, gold, and platinum stars. The proposed tool is considered only for the efficient use of water. The number of drops will be proportional to the reached points, as shown in Table 6, in which five drops represent the highest score of the proposed criteria. The minimum to obtain a seal are two drops, conferred upon reaching 40 points, in addition to the design and operational phases.

Regarding the project, the parameters should be adjusted according to its type, because some items may not be configured with the characteristics of the assessed construction. The parameters connected to the operation and maintenance phase, however, must be preferably fully met, because by operating it, one can know if the expected results were reached. It is not possible to evaluate projects only because they may have been designed with all the concepts favorable to a more sustainable study, but their implementation has undergone modifications that compromise performance.

The criteria may be applied to any tools for comparing the proportionality of the existing weighting with the new weighting of the design and operational criteria proposed in this study. By making an equivalence of the parameters of the AQUA (High Environmental Quality) system, in which the maximum weighting reaches $12.22 \%$, considering the Water Management category plus the Sanitary Quality with the proposed system called +água, the maximum value obtained would be close to $70 \%$, that is, $12.22 \%$ would be equivalent to $8.55 \%$ when the parameters of the new tool were added. Thus, if the AQUA system were applied in Brazil, the parameters would need to be adjusted for the maximum recommended management in the regions of Brazil.

\section{CONCLUSIONS}

Applying a tool created in another country in a direct way will not bring good results and will not be reaching the real concerns, especially in the water issue. The project should not only be adequate to

Table 6 - Credits for Certification.

\begin{tabular}{|c|c|c|}
\hline \multirow[t]{5}{*}{ Green seal } & Design & Operation \\
\hline & 30 & 10 \\
\hline & 40 & 20 \\
\hline & 50 & 30 \\
\hline & 60 & 40 \\
\hline
\end{tabular}


environmental issues, its use and maintenance should also be in synergy with the needs of control of sources and demands for water. That is why operational criteria were proposed, which could guarantee significant gains for saving drinking water.

Civil construction is still mostly conservative in Brazil. The concept of performance, reduction of environmental impacts, use of environmental-based material, and concern with the increase in service life of the construction, are still new factors gradually inserted in the companies. As an incentive, compensation, such as reduction of taxes or increase of urban rates, could be applied by governments in certified undertakings.

Buildings with installation of water and energy saving equipment reduced consumption and, therefore, lowered the costs. A construction that meets environmental requirements guarantees long life and greater durability and, consequently, less maintenance fees, even in recent buildings.

As shown in this study, the tools were developed for different needs and objectives in response to the realities of the country that created it. Therefore, local adaptation is required for greater efficiency in results when applied in other regions. Legal and market factors can influence the decision of choosing a tool, which may not be the most environmentally appropriate. The projects are designed to meet the investors' economic objectives and to comply with the laws in force in the region where they are intended to be built. Sustainability issues are not always considered.

Due to the serious and increasing problems of water scarcity, this study suggests that the criteria presented in Tables 4 and 5, related to the design and operational phase, be included in other tools when they are used in Brazil, taking into account the regional demands. Considering the differences between the mentioned tools, it was not up to the authors to define specific weighting to the criterion of water use and management. The variations presented in the comparisons between the tools, in which many of the parameters are subjective and do not clearly show what can be done as to water management and use, corroborated that a tool for national use should be proposed to measure the performance of water use in built environments.

In conclusion, based on what has been exposed in this paper and comments from various authors, no matter how much each tool evolves, the need to be appropriate to each region is inevitable. In developing countries such as Brazil, it is easier to obtain certifications in large cities in the Southeast region, and it is probably out of the question in regions with serious social problems and low-skilled labor. A tool must be didactical, respecting each community, its culture, and religion. Encouraging good consumption and reuse practices still has a faster result. It is important that there is greater synergy between researchers and professionals regarding the efficient use of water. Every production chain must be engaged to meet the requirements of an environmental assessment system.

There is no better tool. Probably, the best result will come with the joint application of several tools. This includes both the ease of application and the costs for advice and commissioning, as well as the market and legal requirements that may dictate the choice of the most appropriate system. In addition to the search for a certification, there should be concerns such as environmental and social issues, with the certificate as the acknowledgment of a low environmental impact undertaking, with more performance and greater durability and mainly conferring internal quality to its user.

\section{CONFLICT OF INTERESTS}

On behalf of all authors, the corresponding author states that there is no conflict of interests.

\section{REFERENCES}

AGÊNCIA NACIONAL DE ÁGUAS (ANA). ATLAS: Abastecimento Urbano de Água. Available at: <https://www.atlas.ana.gov.br>. Accessed on: Mar. 23, 2017.

ALI, H.H.; AL NSAIRAT, S.F. (2009) Developing a green building assessment tool for developing countries - Case of Jordan. Building and Environment, v. 44, n. 5, p. 1053-1064. https://doi.org/10.1016/j. buildenv.2008.07.015

ANDRADE, J.; BRAGANÇA, L. (2016) Sustainability assessment of dwellings - A comparison of methodologies. Civil Engineering and Environmental Systems, v. 33, n. 2, p. 125-146. https://doi.org/10.1080 /10286608.2016.1145676
ASDRUBALI, F.; BALBINELLI, G.; BIANCHI, F.; SAMBUCO, S. (2O15) A comparison between environmental sustainability rating systems LEED and ITACA for residential building. Bulding and Environmental, v. 86, p. 98-108. https://doi.org/10.1016/j.buildenv.2015.01.001

BASTOS, C:; REBELLO, T. (2016) Análise comparativa entre ferramentas de certificação ambiental relacionadas ao uso e gestão da água. In: Sustainable Urban Communities towards a Nearly Zero Impact Built Environmental. Proceedings...

BCA GREEN MARK. Certification standard for new buildings. 2012. Available at: <https://www.bca.gov.sg/EnvSusLegislation/others/ GM Certification Std2012.pdf>. Accessed on: Jul. 14, 2017. 
BREEAM. BREEAM UK New Construction. 2014. Available at: <https://tools.breeam.com/filelibrary/BREEAM\%2OUK\%20 NC\%202014\%20Resources/sd5076_draft_breeam_uk_new_ construction_2014_technical_manual_issue_0.1.pdf>. Accessed on: Nov. 10, 2017.

BRIBIÁN, I.Z.; USÓN, A.A.; SCARPELLINI, S. (2009) Life cycle assessment in buildings. State-of-the-art and simplified LCA methodology as complement for building certification. Building and Environment, v. 44, n. 12, p. 2510-2520. https://doi.org/10.1016/j. buildenv.2009.05.001CASBEE. Available at: <http://www.ibec.or.jp/ CASBEE/english/downloadE.htm>. Accessed on: Nov. 8, 2017.

CLIMATEMPO. Available at: <https://www.climatempo.com.br>. Accessed on: Jan. 15, 2017.

COLE, R.J. (2005) Building environmental methods redefining intensions and roles. Building Research \& Information, v. 33, n. 5, p. 455-467. https://doi.org/10.1080/09613210500219063

CORE NET GLOBAL. (2014) International Sustainability Systems Comparison. CoreNet Global by Ove Arup \& Partners Ltd.

DARKO, A.; CHAN, A.P.C. (2016) Critical analysis of green building research trend in construction journals. Habitat International, v. 57 , p. 53-63. http://dx.doi.org/10.1016/j.habitatint.2016.07.001

DGNB System. Sustainable and green building. Available at: <http:// www.dgnb-system.de/en>. Accessed on: Feb. 10, 2017.

DING, G.K.C. (2008). Sustainable construction. The role of environmental assessment tools. Environmental Management, v. 86, n. 3, p. 451-464. https://doi.org/10.1016/j.jenvman.2006.12.025

DOAN, D.T;; GHAFFARIANHOSEINI, A.; NAISMITH, N.; ZHANG, T.; GHAFFARIANHOSEINI, A.; TOOKEY, T. (2O17) A critical comparison of green building rating systems. Building and Environment, v. 123, p. 243-260. https://doi.org/10.1016/j.buildenv.2017.07.007

EGYPTIAN GREEN BUILDING COUNCIL. Green Pyramid Rating System Levels. Available at: <http://egypt-gbc.org/ratings.html>. Accessed on: Oct. 3, 2017.

FUNDAÇÃO VANZOLINI. Available at: <http://www.vanzolini.org.br>. Accessed on: Oct. 20, 2017.

GBC BRASIL. Green Building Concil Brasil. Available at: <http://www. gbcbrasil.org.br>. Accessed on: Nov. 11, 2016.

GREEN STAR. Design and construction. Available at: <https://new. gbca.org.au/green-star/rating-system/design-and-built/>. Accessed on: Jun. 25, 2017.

GRÜNBERG, P.; MEDEIROS, M.; TAVARES, S. (2014) Certificação Ambiental de Habitações: Comparação entre LEED for homes, processo AQUA e Selo Casa Azul. Ambiente \& Sociedade, São Paulo, v. 17, n. 2, p. 195-214. http://dx.doi.org/10.1590/S1414-753X2014000200013

HONG KONG GREEN BUILDING COUNCIL LIMITED (HKGBC). Beam Plus V1.2 New Building. Available at: <https://www.hkgbc. org.hk/upload/beamdocuments/BEAM-Plus-NB-1-2-guideline.pdf>. Accessed on: Dec. 15, 2017.
IISBEITALIA. Itaca. Available at: <http://www.iisbeitalia.org/ sbmethod/protocollo-itaca>. Accessed on: Aug. 25, 2017.

LEE, W.L. (2013) A comparative review of metrics of building environmental. Energy and Buildings, v. 62, p. 403-413. https://doi. org/10.1016/j.enbuild.2013.03.014

LEED NC. LEED v4 for Building Design and Construction - current version. LEED NC. Available at: <https://www.usgbc.org/resources/ leed-v4-building-design-and-construction-current-version> Accessed on: Jun. 18, 2018.

MEDEIROS, M.H.F.; ANDRADE, J.J.O;; HELENE, P. (2O11) Durabilidade e Vida Útil das Estruturas de Concreto. In: ISAIA, G.C. (org.). Concreto: Ciência e Tecnologia. São Paulo: IBRACON. v. 1. p. 773-808.

MOREIRA NETO, R.F.M.; CARVALHO, I.C.; CALIJURI, M.L.; SANTIAGO, A.F. (2012) Rainwater use in airports: A case study in Brazil. Resources, Conservation and Recycling, v. 68, p. 36-43. http://dx.doi. org/10.1016/j.resconrec.2012.08.005

MUN, J.S.; HAN, M.Y. (2012) Design and operational parameters of a rooftop rainwater harvesting system: Definition, sensitivity and verification. Journal of Environmental Management, v. 93, n. 1, p. 147-153. https://doi.org/10.1016/j.jenvman.2011.08.024

NGUYEN, B.K.; ALTAN, H. (2011) Comparative review of five sustainable rating systems. Procedia Enginnering, v. 21, p. 376-386.

NICOLETTE, J.; BURR, S.; ROCKEL, M. (2013) A Practical Approach for Demonstrating Environmental Sustainability and Stewardship through a Net Ecosystem Service Analysis. Sustainability, v. 5, n. 5, p. 2152-2177. http://dx.doi.org/10.3390/su5052152

PAHL-WOSTL, C. (2015) Water governance in the face of global change. Switzerland: Springer.

PICCOLI, R.; KERN, A.; GONZÁLEZ, M.; HIROTA, E. (2010) A certificação de desempenho ambiental de prédios: exigências usuais e novas atividades na gestão da construção. Ambiente Construido, Porto Alegre, v. 10, n. 3, p. 69-79.

PRS. Available at: <https://www.upc.gov.ae/en/estidama>. Accessed on: Jun. 15, 2018

SALLAM, I.; ABDELAAL, M. (2015) Relative weight of water efficiency credits: as an indicator to enhance buildings' environmental assessment tools performance. Architectural Science Review, v. 59, n. 5, p. 423-431

SBTOOLPT. Sustainable Building Tool PT. Portugal. Available at: <http://www.sbtool-pt.eu>. Accessed on: Jan. 21, 2017.

SEV, A. (2011) A comparative analysis of building environmental assessment tools and suggestions for regional adaptations. Civil Engineering and Environmental Systems, v. 28, n. 3, p. 231-245. https://doi.org/10.1080/10286608.2011.588327

SINGH, V.P.; KHEDUN, C.P.; MISHRA, A.K. (2O14) Water, Environment, Energy, and Population Growth: Implications for Water Sustainability under Climate Change. Journal of Hydrologic Engineering, v. 19, n. 4, p. 667-673. https://doi.org/10.1061/(ASCE)HE.1943-5584.0000866 
SUZER, O. (2015) A comparative review of environmental concern priorization: LEED vs other major certification systems. Journal of Environmental Management, v. 154, p. 266-283. https://doi. org/10.1016/j.jenvman.2015.02.029

TAYLOR, R.; SONNENFELD, D. (2017) Water crises and institutions: inventing and reinventing governance in an era of uncertainty. Society \& Natural Resources, v. 30, n. 4, p. 395-403. https://doi.org/1 0.1080/08941920.2017.1274208
WIENER, M.J.; JAFVERT, C.T; NIES, L.F. (2O16) The assessment of water use and reuse through reported data: A US case study. Science of the Total Environment, v. 539, p. 70-77. https://doi. org/10.1016/j.scitotenv.2015.08.114

YUAN, H.; SHEN, L. (2011) Trend of the research on construction and demolition waste management. Waste Management, v. 31, n. 4, p. 670-679. https://doi.org/10.1016/j. wasman.2010.10.030 